US Army Corps of Engineers

\title{
Army Roof Management and Improvement Opportunities
}

David M. Bailey

The amount of operations and maintenance (O\&M) funding spent to repair and replace roofs makes up a significant percentage of the Army's overall maintenance and repair budget - about $\$ 200$ million annually. Systemic, integrated solutions offer the Army a great opportunity to save millions of dollars annually in repair and replacement costs, and to avoid incidental costs incurred due to interrupted building occupancy, water damage to interior furnishings, etc.

This report discusses current Army business practices for roof management, investigates technology needs, and identifies opportunities for evolving Army roof maintenance activities into a comprehensive roofing asset management program that will address gaps in current practices. 


\section{Foreword}

This study was conducted for Directorate of Military Programs, Headquarters, U.S. Army Corps of Engineers (HQUSACE) under Project 4A162784AT41, "Military Facilities Engineering Technology"; Work Unit C39, "Roofing Performance Prediction." The technical monitor was Ray Navidi, CEMP-ET.

The work was performed by the Materials and Structures Branch (CF-M) of the Facilities Division (CF), U.S. Army Construction Engineering Research Laboratory (CERL). The CERL Principal Investigator was David M. Bailey. Dr. Ilker R. Adiguzel is Chief, CECER-CF-M, and L. Michael Golish is Chief, CECER-CF. The technical editor was Gordon L. Cohen, I nformation Technology Laboratory.

The Director of CERL is Dr. Michael J . O'Connor. 


\section{Contents}

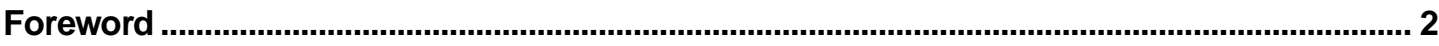

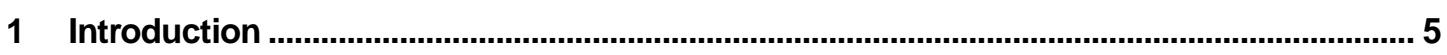

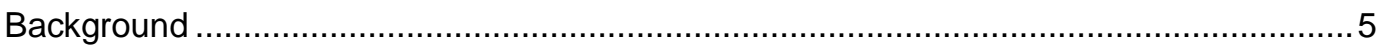

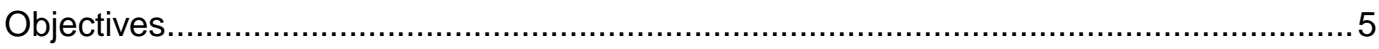

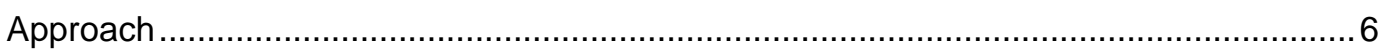

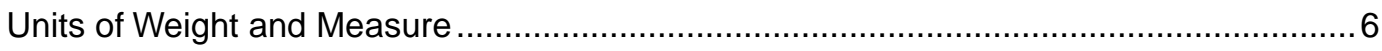

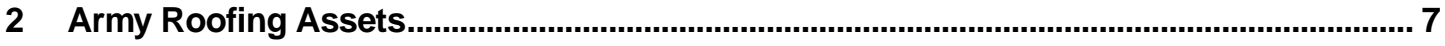

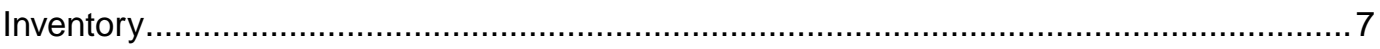

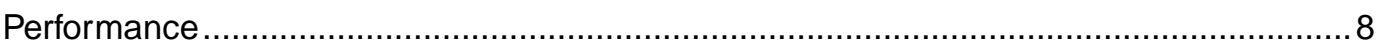

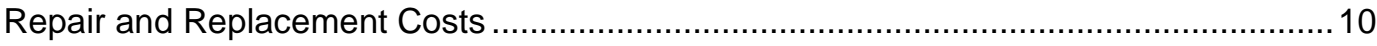

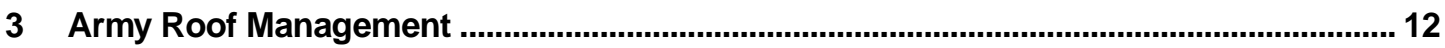

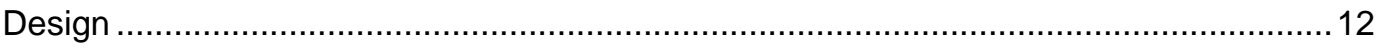

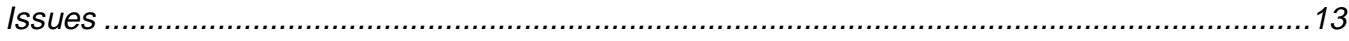

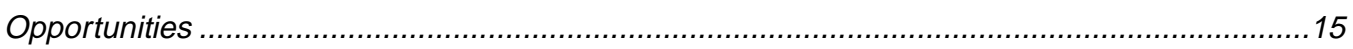

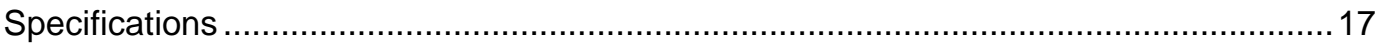

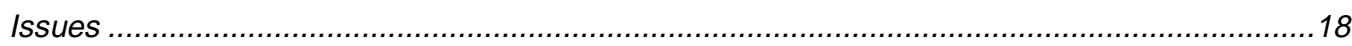

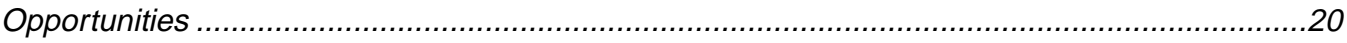

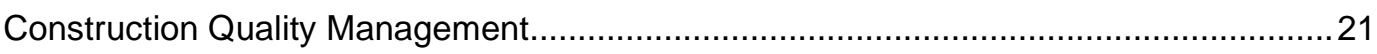

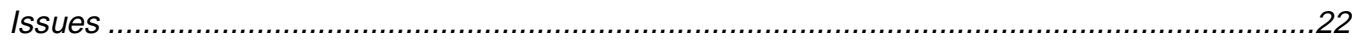

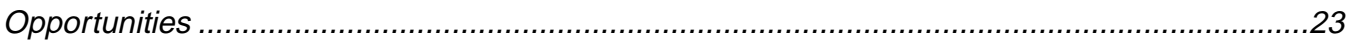

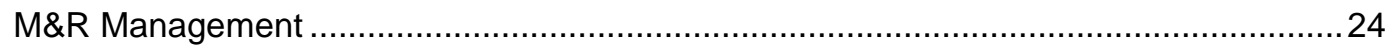

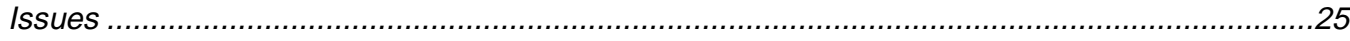

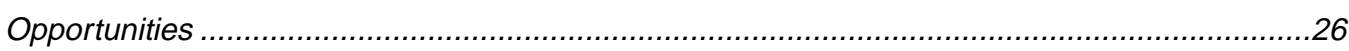

4 Summary

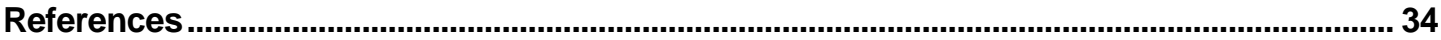

Distribution 


\section{List of Figures and Tables}

\section{Figures}

1 Percentages of roofing area by type on mission-specific buildings, CONUS installations.

2 Percentages of roofing area by type on all buildings, CONUS installations..............30

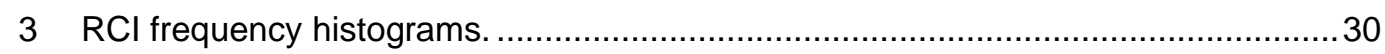

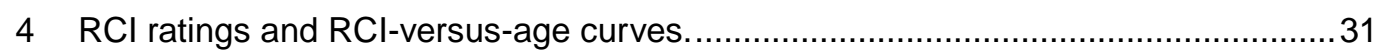

5 Percentages of membrane distress quantities by cause for Army BURs..................32

6 Percentages of flashing distress quantities by cause for Army BURs.......................32

\section{Tables}

1 Army floor and roofing area (SF) for mission-specific and family housing buildings.

2 Estimated total area (million SF) of roofing types for buildings on CONUS installations.

3 Annualized membrane roof replacement costs for all buildings at CONUS installations.

4 Corps of Engineers Guide Specifications (CEGS) for roofing. .33 


\section{Introduction}

\section{Background}

Poor roof performance continues to be one of the most costly and frustrating problems confronting Army installations. The Army currently spends approximately $\$ 200$ million each year to repair and replace roofing. Unfortunately new roofing does not always solve the problem. Some new roofs are problematic from the beginning and will fail well before the end of their expected service lives. Some will fail within a few years of their installation.

As maintenance and repair ( $M \& R$ ) resources become more scarce for the Corps of Engineers and installation directorates of public works (DPWs), concern about poor roof performance grows. This concern is exemplified by such recent activities as the Army Roofing Workshop, which was held in J anuary 1997. This workshop provided a forum for representatives of HQUSACE, Corps districts and divisions, installation DPWs, research laboratories, and industry associations to define the Army roofing problem and begin to find solutions. Thus, it is critical that the Army assess its roofing needs and identify the means for meeting those needs.

\section{Objectives}

The objectives of this report are to:

1. define theArmy's roofing assets, RPMA* (sustainment) requirements, and performance parameters

2. assess current Army roof management practices, shortfalls, and needs

3. recommend opportunities for improvement through changes in business practices and/or adoption of technology solutions.

\footnotetext{
* RPMA: Real Property Maintenance Activities.
} 


\section{Approach}

Roofing-related data were extracted from several sources and cross-checked, then used as the basis for assessing the current Army roofing inventory. The principal sources consulted were:

- Headquarters, Executive Information System (HQEIS) FY97 database

- The Tri-ServiceAutomated Cost Engineering System (TRACES)

- FY96 Directorates of Public Works Annual Summary of Operations (commonly known as the "Red Book")

- ROOFER Engineered Management System (EMS) databases from 21 Army installations, summarized and analyzed in Bailey et al., J une 1997

- Installation maps from Army geographic information system (GIS) databases

- Industry-standard cost estimating guides such as R.S. Means (1998).

In addition to quantitative data, valuable qualitative information and local DPW institutional knowledge were collected through interviews with DPW personnel. Interviews also were conducted with personnel from Army Engineer Divisions and Districts, plus other Corps experts. Other important input was gathered in discussions with industry experts, professional associations, and manufacturers.

A literature review also was conducted, which included pertinent Army and Department of Defense (DoD) technical documents, guidance, and regulations; and proceedings of roofing conferences and workshops.

\section{Units of Weight and Measure}

U.S. standard units of measure are used throughout this report. A table of conversion factors for Standard International (SI) units is provided below.

\begin{tabular}{|lll|}
\multicolumn{3}{|c|}{ SI conversion factors } \\
\hline $1 \mathrm{in.}$ & $=$ & $2.54 \mathrm{~cm}$ \\
$1 \mathrm{ft}$ & $=$ & $0.305 \mathrm{~m}$ \\
$1 \mathrm{SF}$ & $=$ & $0.093 \mathrm{~m}^{2}$ \\
\hline
\end{tabular}




\section{Army Roofing Assets}

\section{Inventory}

The Army is responsible for operating and maintaining approximately 170,000 buildings, which are located at installations all over the world. Based on HQEIS Fiscal Year (FY) 1997 data, these buildings house approximately 1 billion square feet (SF) of floor space and have an estimated total replacement value of \$145 billion. These buildings include residential dwellings and mission-specific facilities such as training, maintenance, production, supply, storage, troop barracks, medical, administrative, and utility buildings. Housing privatization initiatives may shift the management of family housing facilities to the private sector. Despite privatization, however, there will always remain a huge inventory of mission-specific buildings. These facilities currently account for 68 percent of the Army's buildings and 78 percent of total building floor space.

There exists no central database for quantity, condition, and performance of roofing on Army facilities. To assess the Army's current roofing inventory, information was extracted, cross-checked, and extrapolated from several sources. The total amounts of building floor space for individual installations and Major Army Commands (MACOMs) were available from the HQEIS FY97 database and the Directorates of Public Works Annual Summary of Operations (commonly referred to as the "Red Book"). The amounts were reduced to account for Base Realignment and Closure (BRAC) activities. To adjust for multiple stories and varying configurations, the floor areas were converted to roofing area using conversion factors. These factors were derived for representative MACOM installations by:

1. determining the square footage of total roofing using available ROOFER (Bailey et al. 1989) and geographic information system (GIS) databases, and comparing this figure with the total building floor square footage

2. interviewing installation personnel. Similar floor-to-roof area adjustments were made for installations outside of the continental United States (OCONUS) based on general building inventory information obtained from various sources.

Army roofing comprises a variety of materials and systems installed on a wide range of building types. They include (1) low-slope roofing systems such as 
bituminous built-up roofing (BUR), single-ply sheet, modified bitumen membranes, sprayed polyurethane foams, and metal systems; and (2) steep roofing systems that use materials such as asphalt shingle, metal, clay or concrete tile, slate, or wood. Based on estimates developed using the process described above, the Army has a total of 627 million SF of roofing, with 439 million and 188 million on mission-specific and family housing buildings, respectively (Table 1 ).

For mission-specific-buildings, CONUS installations have approximately 77 percent of the Army's total roofing found on these types of facilities. Of this 340 million SF of roofing (Table 2), membrane systems comprise 58 percent of the total area, and metal and asphalt shingle roofing account for 21 percent and 17 percent, respectively (Figure 1 ). The majority of the membrane roofing is BUR, with the remainder being primarily single-ply and modified bitumen systems. (Note: A general summary of roof design and construction materials prevalent in the Army's inventory of membrane roofing systems can be found in Bailey et al., J une 1997.) The family housing buildings on CONUS installations have predominantly steep roofing, most of which is covered with asphalt shingles. For both building types (mission-specific and family housing) on CONUS installations, 44 percent of the roofing is membrane (201 million SF), 35 percent is asphalt shingle (165 million SF), and 15 percent is metal roofing (70 million SF) (Figure 2).

Typical replacement costs per square foot for single-ply and BUR membranes, asphalt strip shingles, and metal roofing systems are $\$ 3.30, \$ 1.00$, and $\$ 5.40$, respectively (Means 1998), not including removal and disposal. Based on these figures, the replacement value for all roofing on CONUS installations is approximately $\$ 1.2$ billion. Extrapolated for the entire Army, this amounts to more than $\$ 1.5$ billion in roofing assets.

\section{Performance}

Poor performance of roofing can be the result of poor design, construction, materials, or the lack of maintenance. When compared to other roofing systems, steep roofing and specifically asphalt shingles require low maintenance and are easily repairable. Based on feedback from personnel at installation DPWs, asphalt shingle roofs have provided their expected level of service. However, the general performance of membrane and metal roofing has not been acceptable.

The roofing industry has for many years accepted the notion that BUR systems should be expected to last 20 years. Perhaps for competitive reasons, similar 
expected service lives for the other membrane roofing systems have been claimed. Based on a 1996 survey of National Roofing Contractors Association (NRCA) roofing contractors located across the United States (Cash 1997), the actual service life for membrane roofing averages 16 years-only 80 percent of the industry-standard 20 year design life.

For the purpose of evaluating the performance of Army roofing, CERL acquired and analyzed ROOFER databases from 21 Army installations. These databases contained historical, design, and construction data for 3059 roof sections, totaling 18 million SF of BUR and single-ply membrane roofing. Inspection data and condition indexes also were available for each of these roofs. The overall condition of each roof was characterized by the roof condition index $(\mathrm{RCl})$ covering a scale of 0 to 100, with 100 being excellent and 33 indicating failure. $\mathrm{RCl}$ frequency diagrams for the roofs grouped by age are shown in Figure 3.

From examining the figures, clearly age is an important factor in overall condition. As can be seen from the diagrams, the distribution of the $\mathrm{RCl}$ is concentrated at higher values for newer roofs. Using the $\mathrm{RCl}$-versus-age curve (Figure 4), a roof section having an $\mathrm{RCl}$ of 10 points or more below that of a "normal" performing roof can be considered to be performing unsatisfactorily. Using the data presented in Figure 3, roofs 5 years or less in age having ratings below "excellent," roofs between 6 and 10 years of age having ratings below "very good," and roofs between 11 and 15 years of age having ratings below "good" are classified as performing at lower levels than should be expected of a typical roof. Based on these conservative criteria, 39 percent of the Army roofs in this sample were providing inadequate service.

Another indication of inadequate Army roof performance may be seen in roof replacement project data from several installations that have implemented ROOFER. From a database of 413 roof sections, 291 (70 percent) of the roofs were replaced before reaching their 20-year design life, and almost half were replaced before 16 years. J ust as alarmingly, 10 percent of these "20-year" roofs were replaced before they reached an age of 10 years. Of the roofs replaced before the age of 16 years, the average age at the time of replacement was 12 years.

Based on the distress data from the Army Micro ROOFER databases, 40 percent of all BUR membrane distresses are caused by poor construction, 29 percent are caused by some combination of construction and design deficiencies, and 8 percent are caused by lack of maintenance (Figure 5). For the flashing components of Army BURs, 47 percent of the problems are caused by poor construction and/or design (Figure 6). 


\section{Repair and Replacement Costs}

The roofing system is one of the most expensive components, when considered over the entire building life-cycle. Roofs may last anywhere from a few years to 40 years or longer depending on material type, performance, and many other factors. In addition to requiring $M \& R$ on a recurring basis, roofs will ultimately reach the end of their useful service life, at which time they must be replaced.

Army roofing repair and replacement costs are not separately tracked but are embedded in overall building $M \& R$ expenditures. However, these costs may be estimated based on private-sector experience. To calculate annual replacement requirements, the average durabilities for single-ply and BUR membranes, asphalt strip shingles, and metal roofing were assumed to be 16 years, 15 years, and 25 years, respectively (Cash 1997). Using unit costs from the Tri-Service Automated Cost Engineering System (TRACES), Means (1998), and other sources for roofing tear-off, disposal, and replacement, the estimated annual roof replacement cost for all CONUS installations is about $\$ 99$ million (Table 3). This extrapolates to $\$ 133$ million for the entire Army. These calculations are supported by information from the field. Using the unit costs and average durabilities noted above, it was estimated that Fort Riley would need about $\$ 1.9$ million annually for roof replacements. Fort Riley DPW personnel reported spending approximately $\$ 2$ million to replace roofs in FY96.

There also are recurring costs for inspecting, maintaining, and repairing roofs. Using an annual cost of $\$ 0.10$ per SF of roofing for these activities, the total annual RPMA cost for roofing amounts to $\$ 200$ million. This is equivalent to 13 percent of the total RPMA dollars spent on Army buildings in FY96.

The early replacement of roofs has a significant impact on the Army's RPMA requirements. Assuming that the acceptable service life is 16 years, the 12-year service life of half the membrane roofing systems on CONUS installations costs the Army an extra $\$ 9$ million annually, as cal culated bel ow:

Annualized replacement cost for 12-year life:

50 percent $\times 201 \mathrm{M}$ sf $\times \$ 4.40$ per sf $\div 12$ years $=\$ 37 \mathbf{M}$ per year

Annualized replacement cost for 16-year life:

50 percent $\times 201 \mathrm{M}$ sf $\times \$ 4.40$ per sf $\div 16$ years $=\$ 28 \mathbf{M}$ per year

Annual cost of poor performance of membraneroofing:

\$9 M per year 
These figures do not include costs resulting from damage to furnishings, lost occupancy, mission interruption, and increased energy costs due to wet insulation. 


\section{Army Roof Management}

The service life of a roofing system is dependent on the designer's knowledge and skill in selecting and combining roofing components, the qualities and characteristics of the individual materials, the quality of installation, and the quality of subsequent roofing maintenance and repair. From an Army perspective, roof management encompasses all activities or processes necessary to ensure the suitable performance of roofing assets throughout their entire life-cycle. These include:

- design and specification

- construction quality management

- maintenance and repair management.

Corps of Engineers District offices are responsible for executing the design and specifications, procurement, and quality assurance phases for new construction projects funded under the Military Construction, Army (MCA) program. Districts also provide these services for other customers, such as the Air Force, Army and Air Force Reserves, and the Veterans Administration. The roof designs for roof replacement projects and smaller building construction projects at Army installations are usually the responsibility of the installation DPW. The roofing $M \& R$ on installations is managed by the local DPW.

Technology issues and opportunities for improvement are discussed below in the context of the defined Army roof management process: design, specification, construction quality management, and $M \& R$ management. Improvement opportunities include changes in business practices, off-the-shelf technology solutions, and technology needs requiring research and development that can improve roof performance.

\section{Design}

To accomplish building design, a typical Corps District has an Engineering Division with an in-house design staff. This staff, which is often located in the Architectural Section of the Design Branch, has several architects to handle the duties of developing and reviewing roof design, detail drawings, and technical specifications. Districts also maintain A-E contracts with design capabilities. 
An in-house designer or an A-E firm may develop the actual project design and specifications, depending upon the Engineering Division workload, expertise, and customer request.

For District projects, all construction documents receive at least one quality control final review by an independent senior-level in-house designer. In addition, the customer and Construction Division perform a Biddability, Constructability, and Operability (BCO) review of the plans and specifications. The construction documents are then transferred to the Contracting Division for public release to prospective bidders, and subsequent contract award.

At Army installations, the roof designs for replacement projects and smaller building construction projects are most often accomplished with the DPW design staff and A-E firms under contract. The design review process tends to be less formal than that for Corps-designed projects. At some Army installations, roof replacement projects are accomplished under a roof requirements contract. This is an indefinite delivery order contract awarded to a roofing contractor on an annual or multi-year basis for the purpose of expediting the process of accomplishing repairs and replacements. For these types of projects, the roof installer con-

structs a roof system, as specified by the contract bid items, often without a formal project design or specifications devel oped by the DPW.

\section{Issues}

During the 1997 Army Roofing Workshop, roof design was recognized as one of several factors controlling satisfactory roof performance. Flaws and inconsistencies in the roofing system design and detail drawings can directly result in poor performance of a well installed roof, and such flaws can also contribute to improper installation by the contractor.

A good roof design requires the appropriate synthesis of many factors, including life-cycle cost, energy conservation, value and vulnerability of building contents, climate, required maintenance, availability of materials and applicators, and environmental impact (Griffin and Fricklas 1996). A designer must have a solid understanding of several principles, including rooftop drainage, thermal insulation, vapor control, wind uplift, fire resistance requirements, and-arguably most importantly-flashing details.

Flashings are the most common sources of roof problems. They require the use of special materials and components to provide watertight terminations at membrane edges and rooftop penetrations. Not surprisingly, many of the Army 
roofing design issues discussed at the workshop were related to flashing details. Such problems include:

- detailing of complicated roofing and flashing intersections that are insufficient or omitted in the design drawings

- use of inadequate flashing details such as embedded edge metal flashing at perimeters and interior gutters, which become chronic maintenance problems

- too much installed equipment placed on the rooftop, which requires extensive and complex flashing details and promotes increased roof traffic.

Designs that do not properly address such factors as condensation, snow, and ice also can create major problems. Typical causes for design inadequacies are (1) project time and cost constraints, (2) insufficiently trained designers, (3) expedient contracting mechanisms that do not specify sufficient government design oversight, and (4) insufficient feedback from installers and end users.

1. Some Army roofing design inadequacies occurring on building construction projects can be attributed to the need to meet project cost and time constraints. For roofing as well as other types of construction, there is great pressure to keep costs down and to complete the plans and specifications in time to meet the project schedule. As a result, the contract documents may lack sufficient detail to convey the design properly, requiring the contractor to work out the deficiencies in the field. For many projects, the particular roofing system submitted by a contractor utilizes the membrane manufacturer's details, but these may be very different from the project design details. Proper and sufficient review of these and other submitted changes may be difficult to accomplish without causing construction delays.

2. Another cause for design inadequacies may be a lack of training for the roof designer. Design architects and engineers receive training in roof design predominantly through on-the-job performance, mentoring, and self-education. During their formal education, architects receive limited class time devoted to roofing materials and design. Whether developing the design or providing review, it is critical that the architect or engineer has a solid understanding of the overall requirements for roof system design. When design problems are not recognized during the review phase, unacceptable performance can be expected. Furthermore, A-E liability for unacceptable performance can be jeopardized due to an ambiguous finding of facts (i.e., whether the problem is a design deficiency or a construction deficiency, or a combination of both).

3. Installation DPW usage of expedient contracting methods, such as roof require ments contracts for roof replacements, is a cause for concern. Considering that 
the large majority of current and future Army's roofing projects are replacements, the quality of roofing procured through such means will have a substantial impact on the overall performance of the Army's roofing assets. Typically, formal design and project specifications are not developed for projects administered under roof requirements contracts. Aside from being required to install a certain generic type of membrane and thickness of insulation, the contractor is allowed significant latitude in what he provides. The Army has little assurance that it is receiving an adequately designed replacement roofing system. The best that can be hoped for, perhaps, is that a manufacturer's standard design is being used, which may or may not appropriately address specific requirements such as fire protection, structural uplift, location, dimate, and user needs.

4. Design quality also can suffer due to insufficient feedback from the installer and the user. As an example, a designer can specify a flashing detail that does not provide sufficient information or proves to be impractical from an installation perspective, or does not serve its intended function as constructed. Sometimes, a particular aspect of the roof design (e.g., interior gutters, nonremovable counterflashing) may result in an excessive maintenance burden for the user. Without a formalized process for communicating these problems back to the designer, they are likely to be repeated.

\section{Opportunities}

The establishment of an internal roofing committee within Engineer Districts and DPWs could formalize the engineering process and help to improve the quality of roof designs and overall roof performance. Committee responsibilities could include sharing expertise, performing final design review, and providing assistance to other parts of the organization on roofing matters. By including roof system designers, construction quality assurance personnel, and end users, the committee could serve as the official channel for ensuring that problems and issues are communicated back to the design staff dearly and rapidly. A designated member of the committee could represent the field by providing expertise for policy meetings, workshops, guide specification development teams, and other roofing-related functions. Secondary benefits, such as the retention of institutional knowledge within the organization, would also be significant. A roofing committee of the general type envisioned has been in place at Louisville District, and has been very successful in keeping personnel efficient and well informed in addressing their roofing concerns. Considering the importance of roof performance to the Army's O\&M bottom line every year, it may now be useful for the Army to define the specific functions and professional composition of valueadded internal roofing committees, and to promote their formation and activity through policy, recommendations, or other means. 
The establishment of an Internet site for the Army roofing community was recommended during the 1997 Army Roofing Workshop. The major functions objectives proposed for the site were (1) to provide up-to-date information on Army and non-Army references, training seminars, and other roofing-related events, and (2) to provide a channel of communication for sharing lessons learned and obtaining expert assistance. In response to this recommendation, an existing Army Internet site for roofing maintenance- the Roofing Information Support System-has undergone substantial improvements and enhancements. The site is not yet fully functional and requires some additional development work. When completed, it should provide an invaluable capability to the entire Army roofing community. A means for promoting and maintaining the site must be established to ensure that it remains effective and up to date. CERL and the Army Cold Regions Research and Engineering Laboratory (CRREL) are positioned to perform these functions, but approval and funding support are required.

Quality roof design from third-party A-Es can be improved when the government sends the request for services to prequalified roofing designers and selects the designer most appropriate for the size and complexity of the job. Aside from meeting the standard requirement of being a registered architect or professional engineer, a requirement for membership in the Institute of Roofing and Waterproofing Consultants (IRWC) International would serve as evidence of both a professional license and roofing design experience. Toward this end, membership with Roof Consultants Institute could also be required. For the convenience of Army contracting personnel, a list of prequalified designers (individuals, not companies) could be posted on the Army roofing I nternet site.

In addition to holding required registrations and memberships, the A-E designer should be able to document experience in the design of roofing in the local area of the project. Too often, designers from a mild climate, such as coastal California, provide inadequate designs for roofs in cold climates. Designing roofs for exposure in Florida without considering the probability of a hurricane, or in Texas without considering the probability of severe hail, are examples of how defective designs can be implemented without full consideration of local conditions.

It would be useful for the Army to consider the benefits of establishing a requirement that all roof designs and specifications be reviewed by an independent designer. This peer review of the designer-of-record's work would apply both to in-house and A-E designs. The small addition to the project cost would provide a great benefit by avoiding serious mistakes that may be uncovered by the independent "second set of eyes." This procedure could also be used to judge the merits of and provide valuable technical feedback to the designer. 
Finally-but maybe most importantly-the practice of procuring roofing projects through roof requirements contracts and similar mechanisms must be carefully examined. These types of projects are becoming commonplace, but they often leave little room for government involvement in the design process. Investigations should be conducted to (1) determine the level and quality of designs used in such roofing projects, (2) assess the processes being used, and (3) recommend improvements for ensuring the expedited procurement of properly designed roofing systems.

\section{Specifications}

Project specifications for military construction address the technical aspects of the work. As per Engineer Regulation (ER) 1110-345-700, Corps of Engineers Guide Specifications (CEGS) are to be used for the technical provisions of the project specifications. The CEGS are developed and maintained by the U.S. Army Engineering and Support Center, Huntsville District. The CEGS are edited or "customized" by the designer to suit the project's particular requirements. A list of the CEGS for roofing is included in Table 4.

CEGS comprise three parts: General, Products, and Execution. The General section contains a listing of references and subsections with requirements for submittals, storage and handling of materials, fire and wind uplift resistance, and warranty. For structural standing seam metal roofing systems, design and additional performance requirements are also included. Several of the roofing CEGS also have a subsection addressing the qualifications of the manufacturer and/or contractor. The Products section contains specific requirements for the materials and components used in the roofing system. Installation procedures for the contractor are stipulated in Execution section.

Industry standards and specifications are referenced extensively in the roofing CEGS. American Society of Testing and Materials (ASTM) standards define initial material property requirements for membranes and component materials that have been determined by the industry to be reliable indicators of good performance. Cited test methods and criteria from ASTM, Factory Mutual (FM), and Underwriters Laboratories (UL) provide requirements for fire and wind uplift resistance. The latter two organizations also perform testing and certifications for complete roofing systems and various component assemblies.

As part of ER 1110-345-700, guidance and policy are provided pertaining to such issues as usage of brand names and proprietary items, and system guarantees. 
The regulation states that specification of brand names is not allowed unless both of the following criteria are met:

1. The particular brand names and products are essential to the needs of the government, and market research indicates that the items meeting project specifications are not available from other companies.

2. The authority to contract without providing for full and open competition is supported by the required justification and approval in accordance with Federal Acquisition Regulation Subpart 6.3.

Very few roofing projects meet the first condition. Therefore, the exclusive use of specific brand name products for roofing is not feasible.

Concerning warranties, ER 1110-345-700 states that beyond the standard oneyear construction warranty from the contractor, extended warranty periods will be specified for materials and systems for which longer guarantees are normally provided in the industry. Manufacturer warranties of 10 years or more have been common for membrane roofing and are used in the current roofing CEGS (Table 4). The regulation also stipulates that the additional cost of an extended warranty, including administration and enforcement costs, must be evaluated before specifying such warranties.

\section{Issues}

The ASTM standards, which exist for the major generic roofing materials such as elastomers, thermoplastics, and modified bitumens as well as metal coatings and corrosion-protection treatments, are typically prescriptive in nature. Although roofing materials and systems meeting these ASTM requirements have generally performed acceptably, their use has not been trouble-free. Examples of such problems include excessive plasticizer loss in the earlier PVC membranes and, more recently, shrinkage of EPDM membranes.

Roofing products are constantly being discontinued, changed, and added to the marketplace. Many of the products used in the original roofing system are no longer available today. Some have been discontinued because of poor performance; others have been dropped because they have been unprofitable due to the strong competition between manufacturers. Competition often spurs producers to consider ways to provide materials at lower prices, resulting in product reformulation. Reformulated materials generally are not proven before introduction into the marketplace, which essentially puts the building owner in the position of providing a test bed for the manufacturers. This presents an ongoing problem because the Army is not permitted to specify by brand name materials 
that have a good performance record and favorable reputation within the industry.

These challenges exist because of the lack of adequate test methods and performance criteria that describe and measure how roofing materials will perform in service. One of the key issues identified by the U.S. roofing industry as part of a 1987 Round Table Seminar (NBS 1987) on roofing research needs was that roofing materials are not properly characterized before being used. Current standards do not ensure good performance over a material's intended service life after being exposed to the outdoor environment. Except for some accelerated aging tests and criteria, which are not correlated to actual exposure conditions, current standards do not provide measures of change in a material after inservice exposure.

Even when the best materials are specified, a dishonest or incompetent contractor can turn them into a substandard roof. Typically, the roofing CEGS require that the contractor be a certified installer by the system manufacturer. This may ensure that the contractor has had at least some training on how to install the product. However, it must be understood that roofing manufacturers make more profit by having more contractors use their product. Therefore, a manufacturer's certification process may be considerably less than rigorous. This problem is aggravated by the fact that disreputable roofing contractors exploit the current government procurement system, which requires "free and open competition" and award to the lowest bidder. The NRCA viewpoint is that many good contractors do not want to do business with the Army because they cannot compete with the "fly-by-night operators."

Roofing system warranties and their value-added to roofing performance have also been a topic of debate within the Army as well as the roofing industry. Most of the roofing CEGS include a manufacturer's standard system warranty of duration, which is typical in the industry for the particular roofing system (see Table 4). It is widely understood that a warranty written by the manufacturer is primarily intended to protect the manufacturer, not the consumer. Additionally, there are times when the manufacturer is unable to inspect the work of their certified contractors, and they are obviously reluctant to reject the work of present (and future) customers.

Historically, the Army has experienced great difficulty in enforcing manufacturer warranties for a variety of reasons. To address this problem, recent metal roofing CEGS (07412 and 07416) were developed to include specific warranty requirements with assignment of liability. Both of these CEGS specifies a 5-year 
contractor's weathertightness warranty and a 20-year manufacturer's material warranty.

\section{Opportunities}

There is a need to devel op methods to predict the long-term performance and expected service life of different roofing membrane materials, metal coatings, and corrosion treatments. Standard tests for acceptance criteria should use accelerated aging methods that can be performed within a few weeks.

As part of the proposed Roofing Service Life Extension research program, CERL will address these needs by conducting research to:

- determine the processes by which roofing materials degrade while in service, and identify the parameters of change

- develop performance models that describe performance of each of the major generic roofing material types (BUR, elastomers, thermoplastics, and modified bitumens) and metal coating and corrosion treatments

- develop performance prediction models through the correlation of materials performance models and accelerated weathering tests

- use these models to establish standard tests and service life criteria for the different roofing materials.

By having performance tests and service life criteria incorporated into ASTM standards and existing roofing systems selection and design guidance, the Army can better ensure that appropriate roofing products are specified and procured.

To ensure that installers of quality roofing systems and materials have the proper training, skills, and expertise, several screening requirements should be considered for use. These include proof of contractor insurance, a good safety record, and a specified minimum number of years of manufacturer certification. For these screening requirements to provide value, a diligent review by government personnel would be necessary.

Factory Mutual has recently undertaken a promising development: a roofing contractor certification program. A draft standard entitled Approval of Roofing Contractors has been distributed to members of the roofing industry for review and comment. The standard is intended to serve as approval criteria for certification of roofing contractors involved in the construction of roof assemblies approved by Factory Mutual Research Corporation (FMRC). It examines the training, education, and abilities of the contractor for the purpose of verifying that the installation of the roofing system will meet acceptable levels of 
performance and quality. If this program comes to fruition, a CEGS requirement for contractors to have FM approval could be instrumental in ensuring that good contractors are retained for roofing projects. The Army should strongly support $F M$ in this effort.

Recognizing the limited value of the manufacturer's warranty in the past, the Army should consider developing its own warranty requirements for the various roofing systems, as has already been done for the metal roofing CEGS. A mechanism is needed to weigh the success of these warranties against additional project costs to determine whether such warranties are worth their cost. The Army should also become more aggressive in prosecuting manufacturers and contractors who do not comply with contract and warranty requirements.

\section{Construction Quality Management}

The Construction Divisions within Corps Districts are responsible for construction management of Corps administered contracts and some DPW O\&M contracts. ER 1180-1-6 provides the policy and guidance for quality management in the execution of these contracts. Per this regulation, quality control (QC) is defined as a contractor's management, control, and documentation of its efforts to comply with contract requirements. Quality assurance (QA), a responsibility of the government, is the system which ensures that the contractor's QC program is functioning properly and that the specified end product is realized. ER 1180-16 requires that the QA effort be commensurate with the value and complexity of the contract.

For Corps-managed projects, the field engineer's QA program includes a pre construction meeting to discuss contract requirements, critical activities, design, and submittals required for the job. A "mutual understanding meeting" between the field engineer and the contractor is later held to discuss the submittal process. Prior to the start of roofing construction activities, the contractor must ensure that submittals as required by the technical specifications have been provided to the government and approved. The Corps field office receives these submittals, which for roofing may include FM and Laboratories (UL) approvals, catalog cuts for materials, material specimens, and shop drawings of flashing and other details.

For roofing (as well as each stage of building construction), a three-phase control process is used by the government's Quality Assurance Representative (QAR) to ensure that the contractor is adequately conducting the required control processes. Typically, a preparatory phase meeting occurs before the start of each 
aspect of roofing construction. During this meeting, the government's QAR and the contractor's Quality Control Representative (QCR) thoroughly review all contractual requirements for the upcoming phase of construction. Once the contractor begins a particular roofing installation activity, an initial phase meeting is conducted on-site between the QCR and the QAR. The purpose of this meeting is to establish the contractually required standard of workmanship. After the construction activity is complete, the QAR conducts a follow-up inspection to ensure that the installation as an end product meets contractual requirements. In addition to this three-phase process, the QAR prepares daily reports that document the government's activities in the day-to-day administration of the contract. These reports include information about weather, contractors/subcontractors on the job, results of control activities, tests performed, equipment and material received, job safety, and remarks.

The construction quality management process for roofing projects managed by the DPW staff varies among installations. A Construction Inspection Branch within the DPW typically performs the quality assurance functions. The branch may have from four to a dozen inspectors who are responsible for all types of construction and maintenance projects. Preconstruction meetings may or may not be held for individual projects, and the entire QA process is informal compared to the three-phase process conducted by Engineer Districts. Contractor submittals are normally passed on to the DPW Project Manager (usually the designer of record), who will execute approvals or may, in the case of out-of-house roof designs, send them to the A-E design firm.

For roofing replacement projects accomplished through a roof requirements contract, a preconstruction meeting with the contractor would typically not be held. One of the primary duties of the construction inspector on such projects would be to validate work and material quantities for payment determination.

\section{Issues}

By regulation (ER 1180-1-6), the contractor is given the responsibility of quality control on construction projects. The QCR, an employee of the contractor, has the duty to ensure that contract requirements are met and that workmanship is satisfactory. Giving the contractor full QC responsibility can best be described by the old adage "having the fox guard the hen house." The government is heavily relying on the specification and procurement processes to ensure that a competent and reputable contractor is awarded the project.

An under-resourced quality assurance program only aggravates the shortcomings of the quality control process. A single QAR is typically responsible for 
quality assurance on all aspects of a building construction project, from foundation to roofing. As recognized by Districts and DPWs, the size of the existing staff compared with the size and complexity of their project load significantly limits QAR time spent on any single project. Due to inadequate staffing or other reasons, insufficient checking of submittals, authorization of field changes without designer approval, and compromise of the formal process of preparatory and preconstruction reviews all have occurred.

\section{Opportunities}

J ust as assigning the contractor to hire its own QC person is not an effective solution, having the manufacturer's representative perform these functions also presents problems. The manufacturer is in business with the contractors and does not want to alienate them. Therefore, it would be best if the QCR or roof monitor were an independent third party. Having the Army hire an independent roof monitor would provide the benefit of "divorcing" the contractor from the QC inspector; thereby strengthening the government's control of the process. A certification program, such as Registered Roof Observer (or RRO, which is operated by $\mathrm{RCl}$ ), could serve as a prequalification process to ensure that a baseline set of qualifications are met.

Among those in the roofing industry, there is little objection to the concept that roof construction deserves good quality control. The quality of the work could reasonably be expected to improve as soon as an inspector or monitor appears on the roof, regardless of the type of roofing specified. An independent, full-time QC inspector could also promote continual communication between the owner, the building occupants, and the contractor, and could serve as a knowledgeable witness in case problems or conflicts arise.

With full-time, third-party QC expected to add only 2 to 4 percent to roofing costs, the customer can easily be convinced of its benefits. Independent field quality control should, at a minimum, be implemented on projects of significant size or complexity, or those using roofing systems or contractors that are unfamiliar to the government or have presented problems in the past. A secondary benefit of having an independent QCR is that competent, reputable contractors will welcome the requirement and tend to bid more Army projects. They also stand to be awarded more jobs since they are less likely to be underbid by a contractor who performs less than desirable work. By putting good and bad contractors on a level playing field-one where their work is under scrutiny in real time -quality work is more likely to be provided. 
The overall efficiency of the Army's QA process also can be improved through implementation of the internal roofing committee, as proposed in the "Design" section earlier in this chapter. The necessary procedures could, without great difficulty, be put in place to ensure that approval of all submittals and field change reviews are handled in an appropriate and timely manner.

\section{M\&R Management}

The installation DPW organizational structure has evolved over many years. Commercial Activities (CA) and privatization initiatives have had great impacts on their functions. As a result of these and other factors, O\&M business processes differ widely among installations. Therefore, in the current context, DPW roof $M \& R$ management is discussed in general terms.

DPWs are required by AR 420-70 to perform annual inspections of their building roofs. In practice, some DPWs perform inspections and preventive maintenance regularly. But this is the exception and not the rule. More often, crisis management-or in the case of roofing-leak management is practiced.

Installations that have routine inspection programs use teams of facility component inspectors to perform visual surveys of each membrane roof every 2 to 4 years. Building roofs that have significant problems are brought to the attention of management by submitting a work request of some type. The major responsibility for conducting detailed follow-up inspections and developing roofing repair and replacement requirements resides with a DPW roofing manager or subordinate. This person may be a branch chief or senior engineer in the Business Management, Engineering Resource Management, or Engineering Division. The roof manager (or a subordinate) conducts visual inspections to assess roof conditions and identify required repairs. A scope of work (SOW) document will then be developed for each repair and replacement project. The actual work may be accomplished using in-house work force, a roof requirements or J ob Order contract, or a competitively bid contract in which design and specifications have been developed.

DPWs that do not have formal inspection programs rely on their leak management process to identify roofs having problems that require further investigation. Those roofs may be identified through work requests generated by the building occupants or a DPW roofer or carpenter. Typically, in these cases, an occupant has initiated a service order after water infiltration has been detected in the building. The responding shop person attempts to trace and repair the 
leak source. If the needed repairs are too extensive, the shop person will generate a work order to have the roof investigated by an engineer.

Approximately 30 Army installations have implemented the ROOFER Engineered Management System (EMS) to assist them in managing the repair and replacement of their BUR and single-ply membrane roofs. ROOFER provides DPW personnel with a decision-support software application (Micro ROOFER) and procedures for collecting inventory and inspection information, and evaluating roof condition. A roof's condition is determined by distresses observed through visual inspection. For insulated roofs, nondestructive moisture surveys may be conducted. Condition indexes generated from inspection data provide objective, consistent assessment of roof condition, repairs needed, and waterproofing integrity.

The DPW roofing managers use Micro ROOFER for data storage and analysis, and to generate management reports. These capabilities enable them to rate their present roof conditions, prioritize projects, and optimally allocate their roofing budget. The managers getting the maximum benefit out of the ROOFER program are using it to determine whether repair or replacement is the optimum strategy for individual roofs, to identify work requirements, and to develop project SOWs.

\section{Issues}

A sound $M \& R$ management program indudes continual inspection and repair of roofing problems plus preventive maintenance. Roofing should be inspected on a regular basis (i.e., every 4 years for membrane roofing systems) to assess roof condition and identify defects that require repair. This process can correct problems early, before they manifest into large problems and allow water infiltration into the roofing system, causing damage to the system, structure, and building contents. Preventive maintenance includes cursory inspections to ensure that roof drains, gutters, and downspouts are unclogged; fixing small problems; and identifying signs of larger roof problems that may require repair or further investigation. They should preferably be scheduled twice a year, in the fall and in the spring.

Crisis management, in which roofs are forgotten until they leak or cause other problems that demand immediate attention, is both disruptive and inefficient. Under this approach, roof anomalies that could have been resolved early with minimal effort and cost go undetected until they become major $M \& R$ requirements. 
A major reason why crisis management is perpetuated in a large organization such as the Army DPW is that it is often easier to obtain funds from higher authority for emergency replacement than for routine inspection and maintenance programs. J ust as "the squeaky wheel gets the grease," the leaky roof gets replaced because it has such a negative impact on the functioning of the building. Other reasons for the persistence of this expensive, dysfunctional practice are:

- Roofs are out of sight and easily forgotten.

- Management's attention is directed el sewhere.

- Building owners have erroneously been conditioned to expect new roofs to last for 20 years with little or no maintenance.

- Competition for funds with other high-visibility projects is stiff.

Unfortunately, some installations DPW personnel believe they are forced into this management practice because of a lack of adequate funds, a lack of personnel knowledgeable in roofing technology, and a lack of specific guidance and management procedures.

Other installations that have implemented asset management programs such as ROOFER (and actively use them) have been able to increase the benefit realized from their roofing O\&M dollars. By having their roofing requirements quantified and documented through the use of standardized engineering procedures, roof managers at these installations have been much more successful in competing against other facility $O \& M$ activities for repair funds. With implementation assistance from the Army Installation Support Center (or ISC, formerly the Center for Public Works) and available training from the Roofing Industry Education Institute (RIEI), these installations have received the necessary support and training to operate and sustain the ROOFER program.

\section{Opportunities}

Installations must invest in proactive roof management to stretch their roof O\&M budgets and improve the condition of their roofing assets. ISC, ACSIM, and CERL have shared success stories from installations and promoted ROOFER through publications, workshops, newsletters, and face-to-face visits with Army roof managers. These efforts should continue, but other means of promoting proactive roof management should also be explored. The realignment of CPW within the Corps (now underway) and the establishment of installation Public Works Service Centers will make it necessary to restructure implementation and technology transfer support for ROOFER. 
ROOFER development should continue, as well. Current Army users of ROOFER have identified a requirement to extend the system from BUR and single-ply roofing to other types of roofing. These types include asphalt shingle, modified bitumen, and metal. Since the last revision of ROOFER in 1995, several new EMS engineering and programming tools (e.g., performance prediction model) and a stand-alone ROOFER geographic information system (GIS) application have been developed. These and other enhancements need to be integrated into ROOFER to enhance its utility. CERL is continually pursuing reimbursable funding sources for integrating these improvements. 


\section{Summary}

The Army roof management process, as compared to the management of other building components and facilities, deserves special consideration for several reasons. With typical service lives for roofing systems ranging from 12 to 30 years, three or more roof coverings may be required over a building's service life. Roofing repair and replacement ( $\$ 200$ million annually) comprises a major portion of the Army's O\&M budget. The Army incurs an added annual cost of $\$ 9$ million due to early replacement of membrane roofing alone. Leaking roofs can have a serious negative impact on a building's mission function and occupancy comfort, and they can result in additional costs from secondary damage to other building systems and content.

Employing any of the proposed roof management improvement opportunities in isolation would not be likely to have a major positive impact on Army roofing performance. Good roofing requires comprehensive asset management, including proper design, materials, workmanship, QC/QA, and proactive maintenance programs.

Similarly, neither changes to business processes, nor application of existing technology solutions, nor research and development advances alone will make the Army more effective in managing its roofing assets. All of these activities must be integrated into a coordinated program that focuses on system-wide improvement of the entire Army roofing inventory. Systematic, integrated solutions offer the Army a great opportunity to save millions of dollars annually in repair and replacement costs. 
Table 1. Army floor and roofing area (SF) for mission-specific and family housing buildings.

\begin{tabular}{|c|c|c|c|c|c|c|}
\hline & Total Building & $\begin{array}{l}\text { Mission- } \\
\text { Specific }\end{array}$ & $\begin{array}{l}\text { Family } \\
\text { Housing }\end{array}$ & $\begin{array}{l}\text { Total } \\
\text { Rofing SF }\end{array}$ & $\begin{array}{l}\text { Mission- } \\
\text { Specific }\end{array}$ & $\begin{array}{l}\text { Family } \\
\text { Housing }\end{array}$ \\
\hline MACOM & Floor SF & & Floor SF & Roofing SF & Roofing SF & Roofing SF \\
\hline$A M C$ & $170,416,000$ & $159,588,000$ & $10,828,000$ & $144,000,000$ & $134,000,000$ & $10,000,000$ \\
\hline FORSCOM & $185,371,459$ & $125,622,873$ & $59,748,586$ & $143,000,000$ & $87,000,000$ & $56,000,000$ \\
\hline TRADOC & $166,577,352$ & $119,101,673$ & $47,475,679$ & $127,000,000$ & $82,000,000$ & $45,000,000$ \\
\hline USAREUR & $169,454,899$ & $108,527,710$ & $60,927,189$ & $84,000,000$ & $43,000,000$ & $41,000,000$ \\
\hline USARPAC & $55,596,637$ & $32,786,946$ & $22,809,691$ & $28,000,000$ & $13,000,000$ & $15,000,000$ \\
\hline Other & $189,038,982$ & $163,859,758$ & $25,179,224$ & $101,000,000$ & $80,000,000$ & $21,000,000$ \\
\hline TOTAL & $936,455,329$ & $709,486,960$ & $226,968,369$ & $627,000,000$ & $439,000,000$ & $188,000,000$ \\
\hline
\end{tabular}

Table 2. Estimated total area (million SF) of roofing types for buildings on CONUS installations.

\begin{tabular}{|c|c|c|c|c|c|c|}
\hline & $\begin{array}{l}\text { Mission- } \\
\text { Specific } \\
\text { Membrane }\end{array}$ & $\begin{array}{c}\text { Mission- } \\
\text { Specific } \\
\text { Metal }\end{array}$ & $\begin{array}{l}\text { Mission- } \\
\text { Specific } \\
\text { Shingle }\end{array}$ & $\begin{array}{c}\text { Mission- } \\
\text { Specific } \\
\text { Other }\end{array}$ & $\begin{array}{c}\text { FH } \\
\text { Shingle }\end{array}$ & $\begin{array}{c}\text { FH } \\
\text { Other }\end{array}$ \\
\hline FORSCOM & 41 & 24 & 18 & 4 & 48 & 8 \\
\hline TRADOC & 39 & 23 & 17 & 3 & 38 & 7 \\
\hline AMC & 104 & 13 & 14 & 3 & 9 & 1 \\
\hline Other & 17 & 10 & 8 & 2 & 13 & 2 \\
\hline Total & 201 & 70 & 57 & 12 & 108 & 18 \\
\hline
\end{tabular}

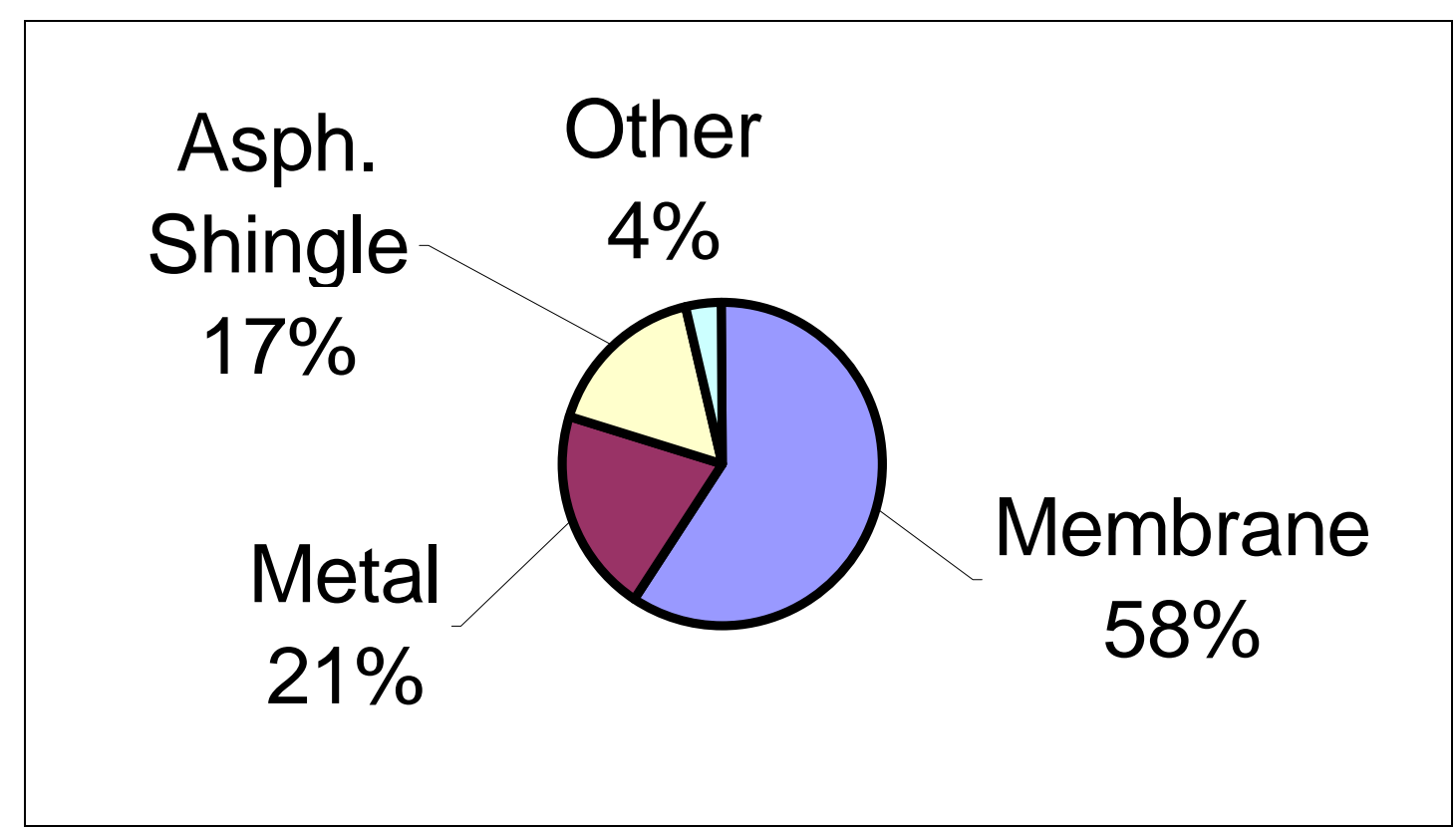

Figure 1. Percentages of roofing area by type on mission-specific buildings, CONUS installations. 


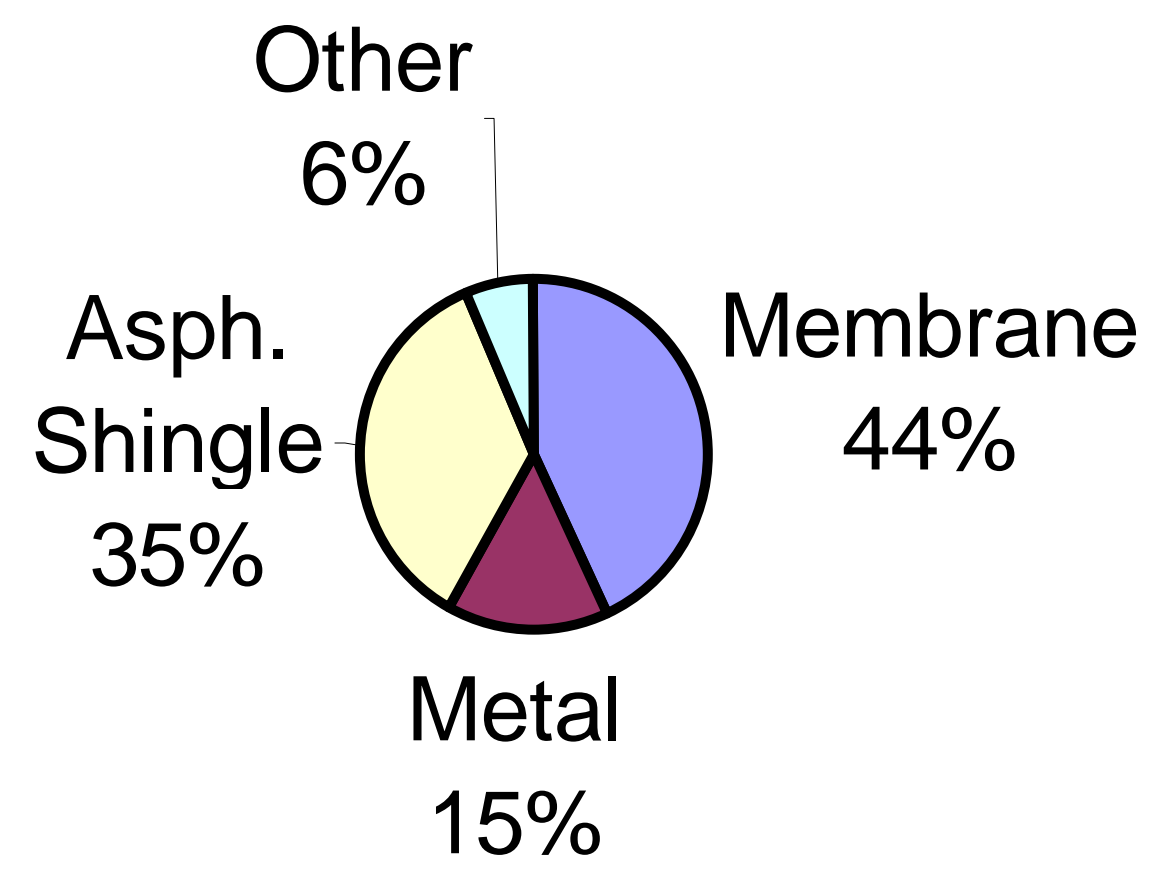

Figure 2. Percentages of roofing area by type on all buildings, CONUS installations.

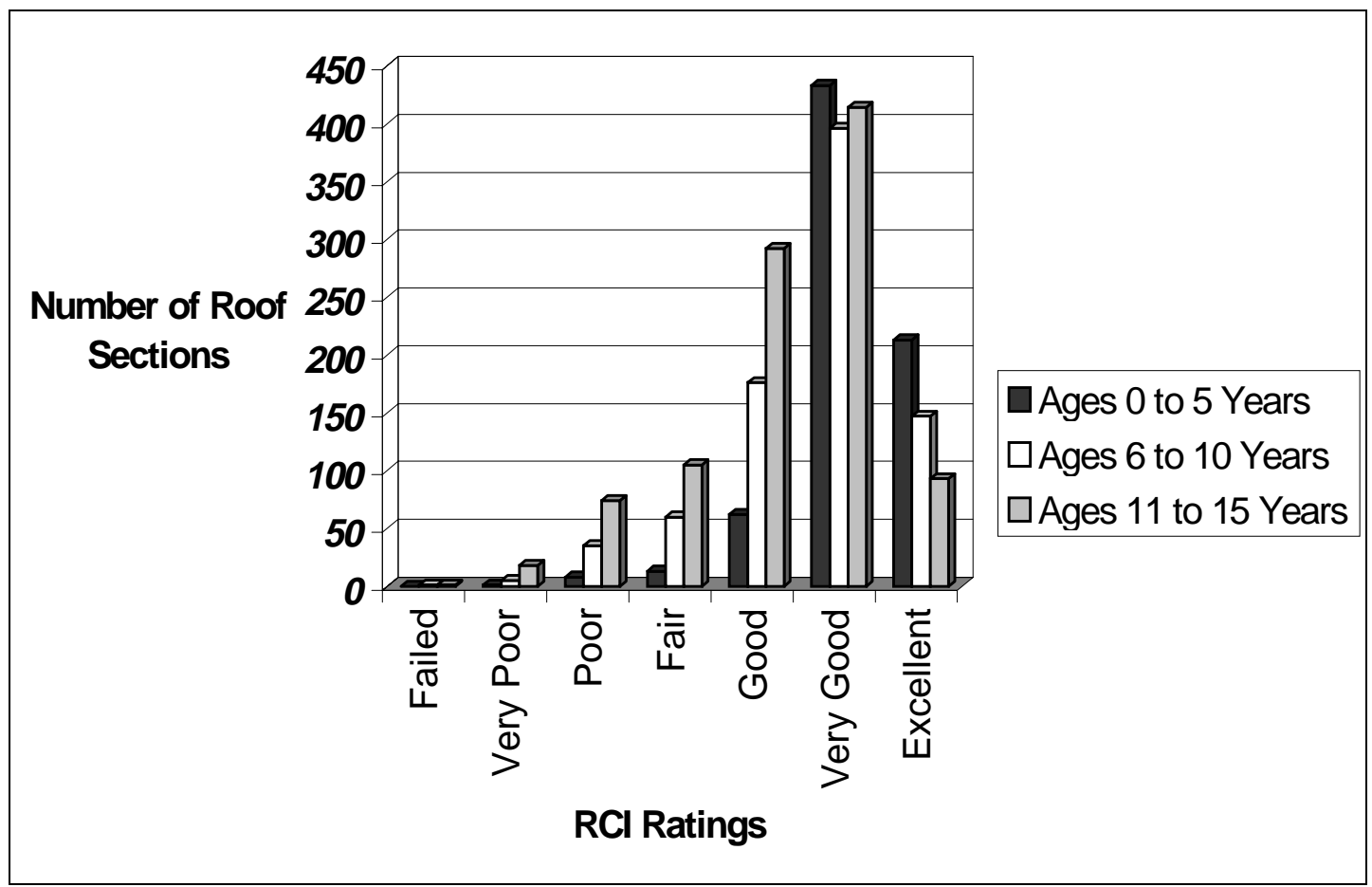

Figure 3. $\mathrm{RCl}$ frequency histograms. 


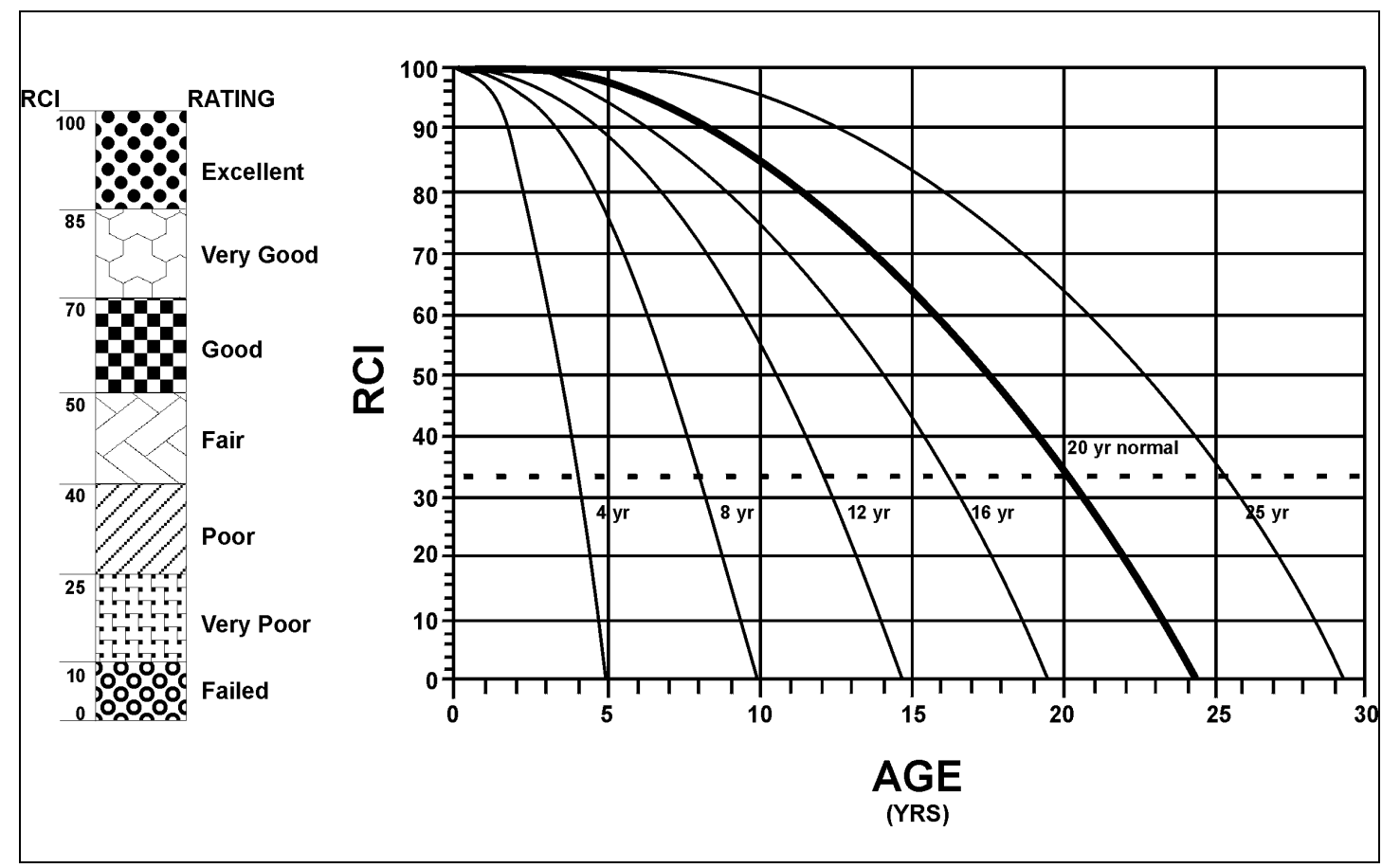

Figure 4. $\mathrm{RCl}$ ratings and $\mathrm{RCl}$-versus-age curves.

Table 3. Annualized membrane roof replacement costs for all buildings at CONUS installations.

\begin{tabular}{|c|c|c|c|c|c|c|}
\hline \multicolumn{7}{|c|}{ Membrane } \\
\hline $201 M$ SF & $x$ & $\$ 4.40 / \mathrm{SF}$ & $\div$ & 16 years & $=$ & $\$ 55 \mathrm{M}$ \\
\hline \multicolumn{7}{|c|}{ Asphalt Shingle } \\
\hline $165 \mathrm{M}$ SF & $x$ & $\$ 1.50 / \mathrm{SF}$ & $\div$ & 15 years & $=$ & $\$ 17 \mathrm{M}$ \\
\hline \multicolumn{7}{|l|}{ Metal } \\
\hline 70M SF & $x$ & $\$ 6.90 / \mathrm{SF}$ & $\div$ & 25 years & $=$ & $\$ 19 M$ \\
\hline \multicolumn{7}{|l|}{ Other } \\
\hline 30M SF & $x$ & $\$ 4.40 / \mathrm{SF}$ & $\div$ & 16 years & $=$ & $\$ 8 M$ \\
\hline TOTAL & & & & & & \$99 M \\
\hline
\end{tabular}

Note: Unit costs include removal and disposal. 


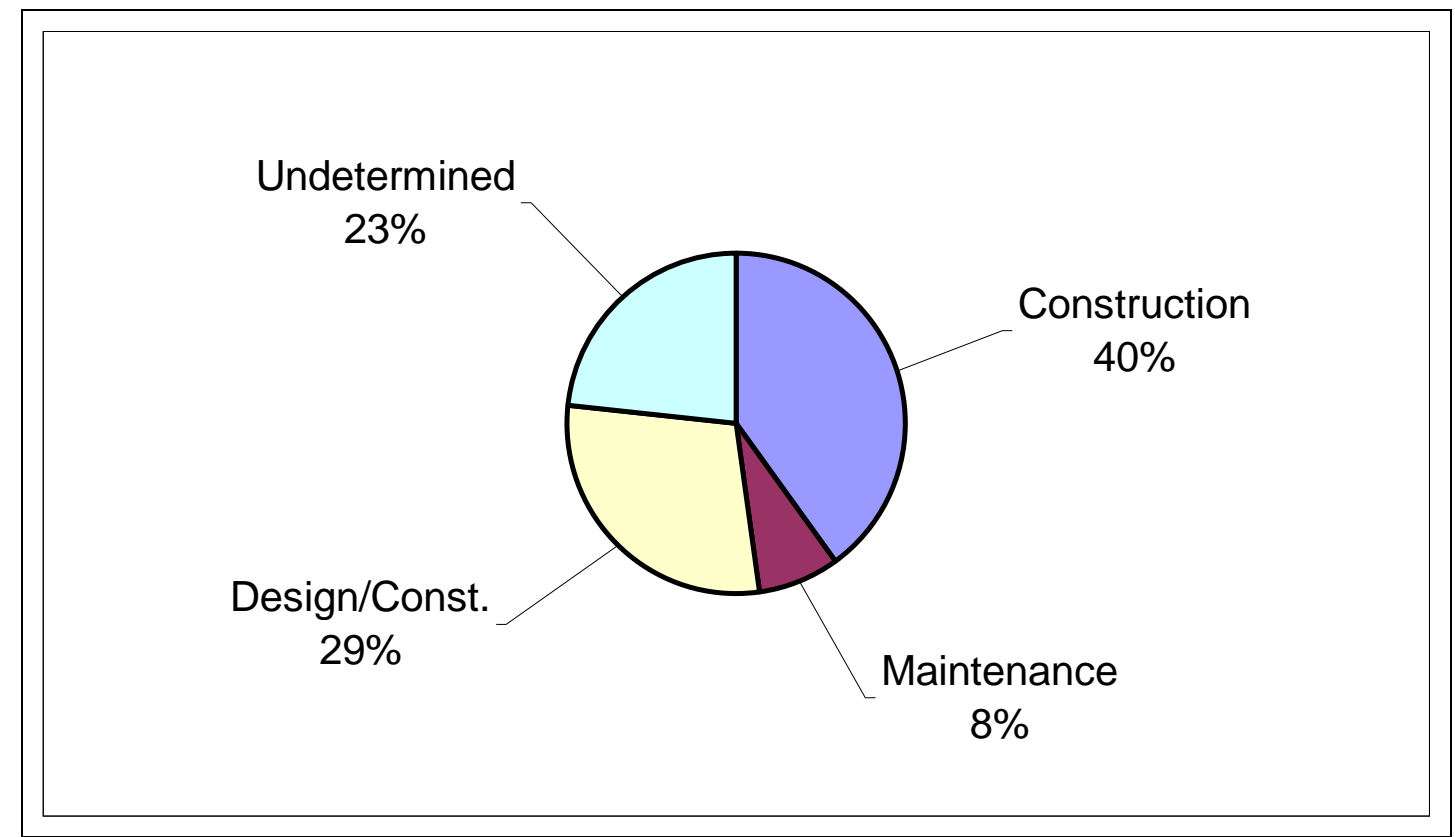

Figure 5. Percentages of membrane distress quantities by cause for Army BURs.

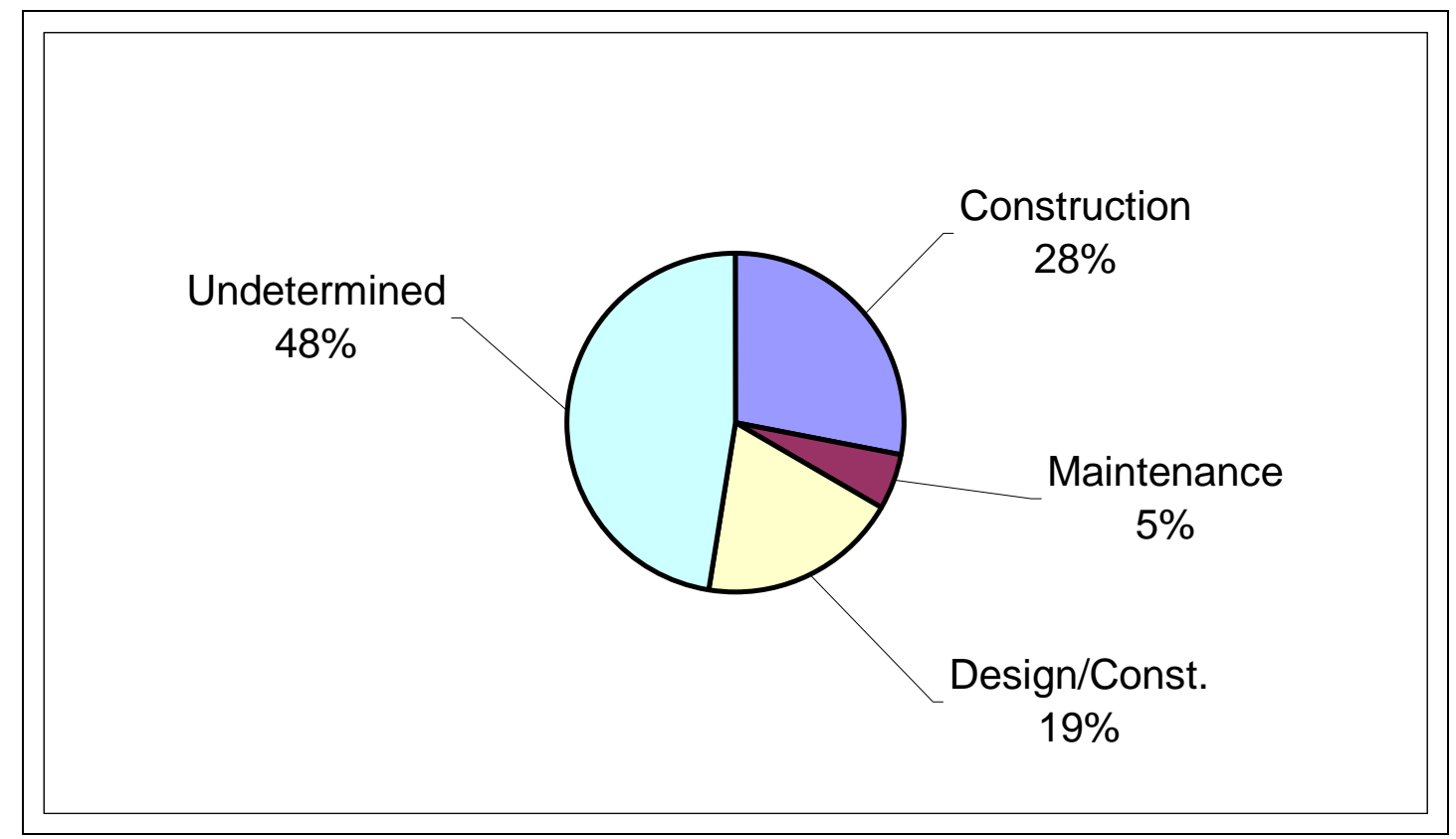

Figure 6. Percentages of flashing distress quantities by cause for Army BURs. 
Table 4. Corps of Engineers Guide Specifications (CEGS) for roofing.

\begin{tabular}{|c|c|c|}
\hline Roofing CEGS & Warranty & $\begin{array}{l}\text { Contractor } \\
\text { Certification }\end{array}$ \\
\hline 07310 SLATE ROOFING & $\begin{array}{l}\text { Matls. \& workmanship - } \\
10 \text { yrs. }\end{array}$ & $\begin{array}{l}\text { Documentation of } 5 \\
\text { yrs of similar work. }\end{array}$ \\
\hline 07311 ROOFING, STRIP SHINGLES & Manuf. std. Warranty. & None. \\
\hline 07320 CLAY TILE ROOFING & $\begin{array}{l}\text { Matls. \& workmanship - } 10 \\
\text { yrs. }\end{array}$ & $\begin{array}{l}\text { Documentation of } 5 \\
\text { yrs of similar work. }\end{array}$ \\
\hline 07412 NON-STRUCTURAL METAL ROOFING & $\begin{array}{l}\text { Contractor - system } \\
\text { weathertightness - } 5 \text { yrs. } \\
\text { Manuf. mtls. \& finish - } 20 \\
\text { yrs. }\end{array}$ & $\begin{array}{l}\text { Manuf. certification } \\
\text { of contractor expe- } \\
\text { rience with } 3 \text { simi- } \\
\text { lar projects. }\end{array}$ \\
\hline $\begin{array}{l}07416 \text { STRUCTURAL STANDING SEAM } \\
\text { METAL ROOFING }\end{array}$ & $\begin{array}{l}\text { Contractor - system } \\
\text { weathertightness - } 5 \text { yrs. } \\
\text { Manuf. mtls. \& finish - } 20 \\
\text { yrs. }\end{array}$ & $\begin{array}{l}\text { Manuf. certification } \\
\text { of contractor expe- } \\
\text { rience with } 3 \text { simi- } \\
\text { lar projects. }\end{array}$ \\
\hline 07510 BUILT-UP ROOFING & None. & None. \\
\hline 07530 ELASTOMERIC ROOFING (EPDM) & $\begin{array}{l}\text { Manuf. std. warranty - } 10 \\
\text { yrs or as specified. }\end{array}$ & $\begin{array}{l}\text { Implied manuf. } \\
\text { approval with } \\
\text { manuf. warranty }\end{array}$ \\
\hline $\begin{array}{l}07548 \text { POLYVINYL CHLORIDE (PVC) } \\
\text { ROOFING }\end{array}$ & $\begin{array}{l}\text { Manuf. std. warranty - } 10 \\
\text { yrs or as specified. }\end{array}$ & $\begin{array}{l}\text { Implied manuf. } \\
\text { approval with } \\
\text { manuf. warranty. }\end{array}$ \\
\hline $\begin{array}{l}07550 \text { PROTECTED MEMBRANE ROOFING } \\
\text { (PMR) }\end{array}$ & Per membrane. & $\begin{array}{l}\text { Manuf. certification } \\
\text { and documentation } \\
\text { of } 2 \text { yrs PMR expe- } \\
\text { rience. }\end{array}$ \\
\hline 07551 MODIFIED BITUMEN ROOFING & $\begin{array}{l}\text { Manuf. std. warranty - } 10 \\
\text { yrs or as specified. }\end{array}$ & $\begin{array}{l}\text { Manuf. approved } \\
\text { for } 3 \text { yrs. }\end{array}$ \\
\hline $\begin{array}{l}07570 \text { SPRAYED POLYURETHANE FOAM } \\
\text { (SPF) ROOFING }\end{array}$ & $\begin{array}{l}\text { Manuf. std. warranty - } 10 \\
\text { yrs or as specified. }\end{array}$ & $\begin{array}{l}\text { Implied manuf. } \\
\text { approval with } \\
\text { manuf. warranty. }\end{array}$ \\
\hline 07610 COPPER ROOF SYSTEM & $\begin{array}{l}\text { Installer leakage and wind } \\
\text { warranty }-20 \text { yrs. }\end{array}$ & $\begin{array}{l}\text { Experience }-10 \\
\text { yrs and } 3 \text { similar } \\
\text { projects. }\end{array}$ \\
\hline
\end{tabular}




\section{References}

Army Regulation (AR) 420-70, Facilities Engineering - Buildings and Structures (Headquarters, Department of the Army [HQDA], Washington, DC, 10 October 1997).

Bailey, D., D. Brotherson, W. Tobiasson, S. Foltz, and A. Knehans, ROOFER: Membrane and Flashing Condition Indexes For Single-Ply Membrane Roofs - Inspection and Distress Manual, Technical Report FM-93/11 (CERL, April 1993).

Bailey, D., D. Brotherson, W. Tobiasson, and A. Knehans, ROOFER: An Engineered Management System (EMS) For Bituminous Built-Up Roofs, Technical Report M-90/04 (CERL, December 1989).

Bailey, D., D. Simpson, X. He, O. Geling, S. Lau, and F. Trachtenberg, Statistical Analysis of ROOFER Database from 21 Army Installations, Technical Report 97/83, ADA326781 (CERL, J une 1997).

Cash, C. "The Relative Durability of Low-Slope Roofing," Proceedings of theF ourth I nternational Symposium on Roofing Technology, Gaithersburg, MD (1997), pp 119-124.

Cash C., and D. Bailey, Predictive Service LifeTests for Roofing Membranes: Phase 1, Interim Re port FM-94/03 (CERL, December 1993).

Directorates of Public Works Annual Summary of Operations, Vol. I - Executive Summary, Fiscal Year 1996 (HQDA, Washington, DC).

Engineer Regulation (ER) 1180-1-6, Contracts- Construction Quality Management (HQUSACE, Washington, DC, 30 September 1995).

Engineer Regulation (ER) 1110-345-700, Engineering and Design- Design Analysis, Drawings and Specifications (HQUSACE, Washington, DC, 30 May 1997).

Engineering I nstructions, Draft-Guidelines for the Selection of Roofing Systems (HQUSACE, Washington, DC, 1 September 1998).

Griffin, C.W., and R.L. Fricklas, Manual of Low-Slope Roof Systems, Third Edition (McGraw-Hill, 1996).

Means Repair and Remodeling Cost Data - $20^{\text {th }}$ Annual Edition, Commercial/ Residential (R.S. Means, Inc., 1998).

National Bureau of Standards (NBS), Summary of the Round TableSeminar - Roofing Research: The Challengeand the Opportunity, December 1987. 
Shahin, M., D. Bailey, and D. Brotherson, Membraneand Flashing Condition Indexes for Built-Up Roofs Volumell: Inspection and Distress Manual, Technical Report M-87/13 (CE RL, September 1987). 


\title{
CERL DISTRIBUTION
}

\author{
Chief of Engineers \\ ATTN: CEHEC-IM-LH (2) \\ ATTN: CEHEC-IM-LP (2) \\ ATTN: CECC-R \\ ATTN: CERD-L \\ ATTN: CERD-M \\ HQUSACE \\ ATTN: CEMP-ET \\ ACS(IM) 22060 \\ ATTN: DAIM-FDP \\ CEISC 22310-386 \\ ATTN: CEISC-E \\ ATTN: CEISC-FT \\ ATTN: CEISC-ZC \\ US Army Engr Distric \\ ATTN: Library (40) \\ US Army Engr Division \\ ATTN: Library (7) \\ US Army Transatlantic Program Center \\ ATTN: TAC 22604 \\ ATTN: TAE 09096 \\ US Army Engineering and Support Center \\ ATTN: CEHND 35807-4301 \\ US Army Materiel Command (AMC) \\ Alexandria, VA 22333-0001 \\ ATTN: AMCEN-F \\ ATTN: AMXEN-C 61299-7190 \\ FORSCOM \\ Forts Gillem \& McPherson 30330 \\ ATTN: FCEN \\ TRADOC \\ Fort Monroe 23651 \\ ATTN: ATBO-G \\ Fort Belvoir 22060 \\ ATTN: CETEC-IM-T \\ ATTN: Water Resources Support Ctr \\ USA Natick RD\&E Center 01760 \\ ATTN: STRNC-DT \\ ATTN: AMSSC-S-IMI \\ US Army Materials Tech Lab \\ ATTN: SLCMT-DPW 02172 \\ USARPAC 96858 \\ ATTN: DPW \\ ATTN: APEN-A \\ SHAPE 09705 \\ ATTN: Infrastructure Branch LANDA \\ Area Engineer, AEDC-Area Office \\ Arnold Air Force Station, TN 37389 \\ HQ USEUCOM 09128 \\ ATTN: ECJ4-EN
}

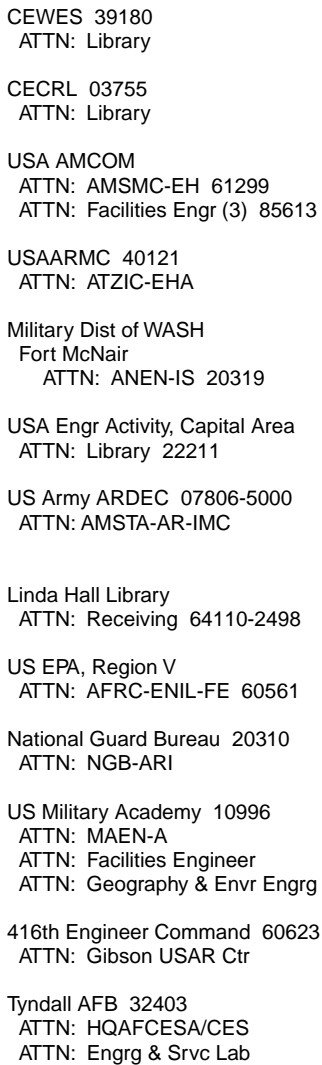

CEWES 39180

ATTN: Library

CECRL 03755

ATTN: Library

USA AMCOM

ATTN: AMSMC-EH 61299

ATTN: Facilities Engr (3) 85613

USAARMC 40121

ATTN: ATZIC-EHA

Military Dist of WASH

Fort McNair

ATTN: ANEN-IS 20319

USA Engr Activity, Capital Area ATTN: Library 22211

US Army ARDEC 07806-5000 ATTN: AMSTA-AR-IMC

Linda Hall Library

ATTN: Receiving 64110-2498

US EPA, Region $V$

ATTN: AFRC-ENIL-FE 60561

National Guard Bureau 20310

ATTN: NGB-ARI

US Military Academy 10996

ATTN: MAEN-A

ATTN: Facilities Engineer

ATTN: Geography \& Envr Engrg

416th Engineer Command 60623

ATTN: Gibson USAR Ctr

Tyndall AFB 32403

ATTN: HQAFCESA/CES

ATTN: Engrg \& Srvc Lab

American Public Works Assoc. 64104-1806

US Army CHPPM

ATTN: MCHB-DE 21010

US Gov't Printing Office 20401

ATTN: Rec Sec/Deposit Sec (2)

Nat'I Institute of Standards \& Tech ATTN: Library 20899

Defense General Supply Center ATTN: DGSC-WI 23297-5000

Defense Supply Center Columbus ATTN: DSCC-WI 43216-5000

Defense Tech Info Center 22060-6218 ATTN: DTIC-O (2) 